OPEN ACCESS

Approved by:

Frontiers Editorial Office,

Frontiers Media SA, Switzerland

${ }^{*}$ Correspondence:

Tanja Restin

tanja.restin@uzh.ch

Specialty section:

This article was submitted to Microbiome in Health and Disease,

a section of the journal

Frontiers in Cellular and

Infection Microbiology

Received: 27 May 2021 Accepted: 02 June 2021

Published: 30 June 2021

Citation:

Senn V, Bassler D, Choudhury R,

Scholkmann F, Righini-Grunder F,

Vuille-dit-Bille RN and Restin T

(2021) Corrigendum: Microbial

Colonization From the Fetus to Early Childhood-

A Comprehensive Review.

Front. Cell. Infect. Microbiol. 11:715671.

doi: 10.3389/fcimb.2021.715671

\section{Corrigendum: Microbial Colonization From the Fetus to Early Childhood- A Comprehensive Review}

\author{
Viola Senn ${ }^{1}$, Dirk Bassler ${ }^{1}$, Rashikh Choudhury ${ }^{2}$, Felix Scholkmann ${ }^{1}$, \\ Franziska Righini-Grunder ${ }^{3}$, Raphael N. Vuille-dit-Bille ${ }^{4,5}$ and Tanja Restin ${ }^{1,5 *}$ \\ ${ }^{1}$ Newborn Research Zurich, Department of Neonatology, University Hospital Zurich and University of Zurich, Zurich, \\ Switzerland, 2 Division of Transplantation Surgery, Department of Surgery, University of Colorado Hospital, Aurora, CO, \\ United States, ${ }^{3}$ Division of Pediatric Gastroenterology, Hepatology and Nutrition, Children's Hospital Lucerne, Lucerne, \\ Switzerland, ${ }^{4}$ Department of Pediatric Surgery, University Children's Hospital of Basel, Basel, Switzerland, ${ }^{5}$ Institute of \\ Physiology, University of Zurich, Zurich, Switzerland
}

Keywords: microbiome, microbiota, fetus, newborn, infant

\section{A Corrigendum on}

Microbial Colonization From the Fetus to Early Childhood-A Comprehensive Review By Senn V, Bassler D, Choudhury R, Scholkmann F, Righini-Grunder F, Vuille-dit-Bille RN and Restin T (2020). Front. Cell. Infect. Microbiol. 10:573735. doi: 10.3389/fcimb.2020.573735

\section{INCORRECT AUTHOR NAME}

In the original article, an author name was incorrectly spelled as Raphael N. Vuille-dit-Bile. The correct spelling is Raphael N. Vuille-dit-Bille.

The authors apologize for this error and state that this does not change the scientific conclusions of the article in any way. The original article has been updated.

Copyright $(2021$ Senn, Bassler, Choudhury, Scholkmann, Righini-Grunder, Vuille-dit-Bille and Restin. This is an open-access article distributed under the terms of the Creative Commons Attribution License (CC BY). The use, distribution or reproduction in other forums is permitted, provided the original author(s) and the copyright owner(s) are credited and that the original publication in this journal is cited, in accordance with accepted academic practice. No use, distribution or reproduction is permitted which does not comply with these terms. 